\title{
CIVIL SERVANTS RATIONALIZATION IN INDONESIA
}

\author{
Rusliandy \\ Doctoral Program Student of Public Administrative Science \\ Universitas Padjadjaran \\ Bandung, Indonesia \\ rusliandy1980@gmail.com
}

\author{
Ega Megawati \\ Regency Government of Bogor \\ Bogor, Indonesia
}

\begin{abstract}
The Ministry of State Apparatus Empowerment and Bureaucratic Reform has announced its rationalization policy plan for 1 million civil servants that will be done in the near future, by classifying all civil servants into 4 quadrants with the indicators on performance, qualification conformity and competence. This study focuses on the civil servants rationalization policy. The result to be obtained is that the civil servants rationalization policy is a strategic policy aiming to improve bureaucracy performance, but the policy is hard to be implemented in short term. There are a number of obstacles and problems that must firstly be handled by the Government before the civil servants rationalization can be implemented. The obstacles that must firstly be anticipated is the regulation aspect by revising Law Number 11 of 1969 and the Government Regulation Number 32 of 1979 . While the problems that must be handled is civil servants equalization problems especially education and medical workers, policy problems and employees recruitment mechanism, employees competence through trainings and formal education, performance, and regional expansion. This policy must also supported by moratorium policy for regional expansion, or should develop a consolidation of regions that failed in executing their autonomy functions.
\end{abstract}

Keywords-Civil Servants; Rationalization

\section{INTRODUCTION}

The Government through the Ministry of State Apparatus Empowerment and Bureaucratic Reform (PAN-RB Ministry) conveyed to the public regarding its rationalisation plan of 1 million civil servants that will be started in 2016 until 2019 and will be continued until 2024. The mapping of civil servants has been started in 2016 and will be continued until 2019. However, such policy is treated differently by the President Jokowi. The President stated that rationalization shall not be done in near future, and the civil servants rationalization shall be done naturally. This matter has been troubling the civil servants, and confusing some parties. There are a number of reasons to execute the civil servants rationalization, among others as follows: first, 5\% or IDR35 trillion budget saving from the total budget of employees and pensioner in the National Revenues and Expenses Budget (APBN) in 2016 which was IDR707 trillion. PAN-RB Ministry has targeted decrease in national budget for civil servants from $33.8 \%$ to become $28 \%$ from the total APBN/Domestic Revenues and Expenses Budget (APBD) within the period of 2015-2019. The said saving fund will be assigned to fund infrastructure, Next Creating ideal ratio. PAN-RB Ministry conveyed that the rationalization will be done until the number of civil servants reaches the ratio of $1.5 \%$ from the total population or at the number of 3.5 million. Based on the study of PAN-RB Ministry, currently the civil servants ratio is still in the neighborhood of $1.77 \%$ from the population. The Ministry stated that China has one billion population with civil servants of merely 4 million. And The number of civil servants of 4.5 million is considered excessive. The PAN-RB Ministry has ilustrated that China has successfully decrease its number of civil servants within three years, from 1997 to 2000 . This decrease was started from management of organization, namely decrease of approximately $30 \%$ organization in central level and $20 \%$ organization in provincial level. China has succeeded decrease $47 \%$ of its number of civil servants, from approximately 8 million to become 4 million in 2000 . In principle, rationalization program was aimed to improve public services quality.

However, the policy plan proposed by the PAN-RB Ministry was treated differently by the President. The President stated to various media that civil servants rationalization shall be done naturally. The President provided samples that civil servants rationalization in a year happened in retirements that reached 120 thousands employees, thus within 5 years there would only be 60 thousands recruitment. The President also confirmed that rationalization shall not be done in short term. This proposal was only in conceptual stage in Ministry level and had not been formally proposed to the President. The different statements between the President and PAN-RB Ministry was confusing to a number of parties and civil servants. This matter sparks controversies in deciding the way of bureaucracy reformation in the future. Considering this matter, it is interesting to study civil servants rationalization in Indonesia.

\section{RESEARCH METHOD}

The study is focused on the plan of civil servants rationalization policy. This study uses descriptive method by analysing various documents, media as well as observation to 
obtain information on what, how and why the civil servants rationalization policy is planned.

\section{LITERATURE REVIEW}

\section{Professionalism}

Stated that professionalism is calculated from its speed factor in performing function and refers to the simplified procedure [1]. The professionalism concept in the individual of an officer can be seen from the following factors: (1) creativity; (2) innovation; (3) responsivity. Stated that professionalism is not formed and affected with merely skills and knowledge so that the officers can perform their tasks and functions effectively and efficiently, but also affected by philosophy of bureaucracy, values, structures and working procedure in bureaucracy [2]

Hegel states the three-group concept in the public, namely particular interest group, represented by entrepreneurs and professionals, general interest group, represented by the State, and bureaucracy group. Hegel wanted the bureaucracy was placed on the middle position as a medium between general interest group and particular interest group. Further, referring to Wilson, bureaucracy as an institution that implements political policy, in relation with bureaucracy neutrality, is placed outside of political area. Therefore the issues on bureaucracy/administration shall only be related with business issues and must be free from any political affairs (the hurry and strife of politics).

\section{RESULT AND DISCUSSION}

Burden of APBD was not only for active civil servants, but also for civil servant retirees. Within 2011-2015, civil servants that reached BUP (56 years old before Law Number 5 of 2014) were 739,420 employees in addition to the civil servants with BUP of 60-65 years old (certain functional positions such as Doctor, Main WI, Professor, structural Officer of Echelon I and II etc.,) which were 424,961 employees that make a total of $1,164,381$ employees or $24.6 \%$. The number of civil servants who have retired up to 2015 was really huge considering the government's expenses burden to fund the retirees were even increasing. This situation was caused by several causes, among others First, the system adopted by Indonesia up to now was still using Pay as you go. and not fully funded system. Currently the subscription mechanism received from participants based on the Government Regulation Number 25 of 1981 is $8 \%$ for pension program, $2 \%$ for medical and $1 \%$ for housing saving. However, the subscription is paid by only the participants, while the employer (the Government) does not pay anything and thus there is no pension fund as can be found in fully funded system. It causes the APBN is fully allocated to pay pension fund of the civil servants. This stipulation is in contrary with Law Number 40 of 2004 regarding National Social Security System on the obligations of employers. Comparing to several ASEAN countries, it is only the
Government of Indonesia (employer) who does not pay pension fund.

The Government's policy in relation to increase of salary for civil servants and retirees annually (except in 2016) affected the amount of pension of the civil servants, because the current amount of pension based on Law Number 11 of 1969 uses the formula $2.5 \% \mathrm{x}$ working period $\mathrm{x}$ latest main salary, with a maximum line of $75 \%$ and minimum line of $40 \%$. It was also caused by our pay as you go system in pension payment.

The similar thing also happens in the competence of apparatus. There is negative outlook on the apparatus from the ex-President of Indonesia as well as ex State's Apparatus Empowerment Minister. While actually the ones who have such negative outlook come from the people who should be responsible to the formation and development of the same apparatus and bureaucracy. The following are the negative outlooks:

Similar situation had also been developed by the city government of Bogor in 2012. The City Government of Bogor allowed civil servants who had reached 50 years old to take early retirement with a condition that their working period had reached minimum 20 years. This program was aimed to decrease the number of civil servants. For those who agree to take the early retirement program, if he/she is 51-52 years old then he/she would receive a compensation in the amount of 24 times of his/her main salary, and for civil servants within the age of 53-54 years old, he/she would receive a compensation in the amount of 18 times of his/her main salary. However, its implementation was stop after the issuance of Home Affairs Minister Regulation Number 37 of 2012 regarding APBD Guidelines for Budget Year of 2013. This Regulation prohibits domestic government to budget gratia expenses to PNSD and also prohibits any offer to PNSD who take early termination of any severance payment, since there is no legal basis for such payment. These prohibitions are reconfirmed in Home Affairs Minister Regulation Number 52 of 2015 regarding APBD Guidelines for Budget Year of 2016.

From the point of view of regulation, early retirement or voluntary retirement with pension rights is stipulated under articles 2 and 17 of Governmental Regulation Number 32 of 1979 regarding Termination of Civil Servants. This Regulation stipulates that civil servants who are terminated with honour shall be entitled for pension if they have reached the age of 50 years old and pension working period of at least 10 years. However, there is no legislation that stipulates provision of severance or compensation for those who apply for early retirement. It can be understood because up to now the system adopted by Indonesia for civil servants is still pay as you go and not fully funded system. With this system, more retired civil servants especially early retired, will be the burden of Government budget. 


\section{Determination of criteria}

Determination of classification for all state's apparatus into the 4 quadrants with the approaches of performance, comp ability on qualification, competence and discipline are not in line with the ASN criteria desired under consideration of Law Number 5 of 2014. Several criteria that have not been considered are integrity, free from KKN, neutral and free from political intervention, and professional civil servants. While actually those criteria are the basis in creating a clean government. If such criteria are not considered, then it will be hard to eradicate KKN practices.

\section{Competence of civil servants}

Bureaucracy is one of the factors and the main factor that support a clean government and good governance. In this very important position and role in the management of public policy and services, bureaucracy become a very defining factor for efficiency and quality of services to the public, as well as efficiency and effectivity of governmental and development operation. An ideal bureaucracy is a bureaucracy that is supported by competent apparatus who can perform well.

\section{1) Government Policy and its implication to the competence of civil servants \\ Recruitment Policy}

Researches from the Adgers International University, Norwegia, and by the World Bank through Decentralization Support Fund project, have shown practices of sale and purchase of civil servants formation between employment authority in central government and domestic leaders [3]. The formation that obtained with IDR5-10 million capitals per civil servant is sold to Authorized Official in domestic areas with much more expensive price, approximately within IDR 75 million to IDR 150 million, depends on the position. The trading practices of civil servant candidates not only value really high annually, approximately IDR 20 to 25 trillion per year, but also harm morality pillars of state's civil servants. Trading practices for position also happens in formation of head of Working Unit for Domestic Apparatus (SKPD) and domestic political positions. It shows that employment decentralization under Law Number 43 of 1999 has deviated from the spirit to support domestic governments to be able to adjust the number and quality of domestic civil servants with the function and tasks in domestic governments. The fact is that up to 2012, there is no employment management operated with expected spirit, namely to appoint civil servants whose number, composition and qualification are in line with the burden of duties and function in relevant domestic area.

\section{Development of employees' competence}

Implementation of competence development as happening at the moment has a number of weaknesses, some of them have even deviated. Competence development can be done through education and training in structural/functional/technical, study assignment and study permit to continue education to a higher level or other competence development forms. However, in practice there are a number of civil servants who did not want to participate in the trainings. There are civil servants who as from their appointment up to retirement had only 1 training, and that was a pre-posting training. Training programs is not related yet to career development. There are civil servants who already participated in leadership trainings but they have not been promoted afterwards, in contrary, there are people who have been promoted without participation in leadership trainings. Same thing happen in competence development through formal education. There are a number of cases where civil servants use fake certificates for their recruitment, career development, promotion or even to meet qualification requirement for teachers as happened in South East Sulawesi Province that reach to 500 civil servants. These problems must be handled immediately by the Government if it wants to achieve the vision and missions of bureaucracy reformation, namely government operation with worldwide standard.

\section{Performance of civil servants}

Performance assessment system as regulated under Government Regulation Number 46 of 2011 is still weak. There are many Employees Working Objectives (SKP) that have not been made by inferiors or certain persons. SKP targets that are made are also the same with previous years, or there is no improvement and innovation. SKP targets are made as is, and worsen by no competence and independent evaluator. All this time only direct supervisors who become evaluators. And those direct supervisors do not fully understand the said Government Regulation Number 46 of 2011.

In relation to sanction to civil servants who fail to reach performance target is also still weak. Articles 9 and 10 of Government Regulation Number 53 of 2014 regarding Disciplinary of Civil Servants only stipulate the following matters: the civil servants who at the end of the year only achieve approximately $25 \%$ to $50 \%$ of their determined working targets subject to medium disciplinary sanction (postponement of salary payment, postponement in promotion or demotion in a year). And for civil servants who at the end of the year achieve less than $25 \%$ of their working targets are subject to hard disciplinary sanctions (demotion in 3 years until termination without honour as a civil servant).

\section{Regulation on Golden Shake Termination and Retirements}

Regulation on termination and retirement of civil servants currently refer to Law Number 11 of 1969 regarding Employees and Widowers Pension and Government Regulation Number 32 of 1979 regarding Termination of Civil Servants. Law Number 11 of 1969 stipulates that employees who are terminated with honour from their post as civil servants shall be entitled to employees pension, if they, in their termination as civil servants: a. have reached the age of at least 50 (fifty) years old and passed a working period for pension of at least 20 (twenty) years; b. based on a body/official as appointed by the Health Ministry based on 
regulations regarding medical test for civil servants, are declared not able work anymore in any position due to their physical or mental condition caused by and because their performance of their obligations in their posts; or c. passed a working period of at least 4 (four) years and based on a body/official as appointed by the Health Ministry based on regulations regarding medical test for civil servants, are declared not able work anymore in any position but not due to their physical or mental condition caused by and because their performance of their obligations in their posts.

The said law also regulates terminated civil servants or civil servants who are cleared from their posts due to elimination of their posts, change in employees composition, arrangement of state apparatus or due to other official reasons that make them terminated as civil servants, shall be entitled to employees pension if they are terminated with honour and at the time of termination have reached the age of 50 (fifty) years old and passed working period of at least 10 (ten) years.

Meanwhile, for civil servants who has served a state duty, they cannot rehired as civil servants, but are entitled to employees pension if they are terminated with honour and at the time of termination have reached the age of 50 (fifty) years old and passed working period of at least 10 (ten) years.

Further, Government Regulation Number 32 of 1979 stipulates that the form of termination for civil servants shall consist of voluntary termination, retirement, termination due to simplification of organization, termination due to breach/crime action or misappropriation, termination due to absence in duty, termination due to physically or mentally incapable, termination due to death. This Government Regulation does not recognize termination as planned in civil servants rationalization proposed by the PAN-RB Ministry. Therefore, legal basis for this purpose is still extremely weak. If rationalization would still be done, there must be a revision first to Law Number 11 of 1969 and Government Regulation Number 32 of 1979. Over staff and under staff conditions, as well as civil
servants distribution problem

\section{Teachers requirement}

The data from PAN-RB Ministry records lack and excess of teachers in a number of areas as follows: (1) kindergarten level requires more teachers in 10 Regencies/Cities and 8 Provinces, while excess of teachers is found in 389 Regencies/Cities and 33 Provinces; (2) elementary school level requires more teachers in 418 Regencies/Cities and 34 Provinces, while excess of teachers is found in 59 Regencies/Cities and 24 Provinces: (3) junior high school level requires more teachers in 353 Regencies/Cities and 33 Provinces, while excess of teachers is found in 119 Regencies/Cities and 27 Provinces; (4) high school level requires more teachers in 117 Regencies/Cities and 31 Provinces, while excess of teachers is found in 316 Regencies/Cities and 33 Provinces.
Lack of teacher problem is currently caused by, among others, unequal distribution of teachers. Implementation of Joint Regulation of five ministers, namely National Education Minister, PAN-RB Minister, Home Affairs Minister, Finance Minister and Religion Minister Number 05/X/PB/2011, Number SPB/03/M.PAN-RB/10/2011, Number 48 of 2011, Number 158/PMK.01/2011, Number 11 of 2011 regarding Arrangement and Equalization of Civil Servant Teachers, is not going effective and optimum. This is caused by several factors, among others as follows: first, authorization and responsibilities of teachers is on the domestic government. Distribution will face difficulties for inter-regencies/cities. Domestic government can only perform a mapping for its relevant area. Next teachers are not ready to be posted in remote areas by reasons that the salary is not sufficient, no official house, far from their family, and high transportation cost. This is in line with the survey done by Teacher Report Cards that stated $87.50 \%$ teachers in urban area would likely refuse to be assigned to remote schools. Next, not all teachers meet their obligation of teaching load of minimum 24 hours per week. Even if they meet this obligation, they have done so by teaching in private schools that causes increase in number of teachers in urban area. It is caused by the minimum supervision from domestic and central governments, as well as the non-strict sanctions. Last Politicization of teachers, Indonesian Corruption Watched stated that a number of teachers assignment were done based on political reasons rather than necessity of the schools.

\section{- Medical workers requirement}

Health Ministry stated that Indonesia still lack of general practicing doctors for 12,731 doctors. In 2010, it was recorded that 1,600 clinics (puskesmas) has no call doctors. Even tempo newspaper on 27 March 2013 stated that from 9,000 puskesmas in Indonesia, there are approximately 3,000 units that still has no doctor, especially for those puskesmas located in remote areas.

The difference in doctors' availability can be seen in the doctors' ratio between provinces. Doctor ratios in several provinces exceed the current national average of 33/100,000 people. In Yogyakarta, the doctor ratio reaches 69/100,000 people; in Semarang city, the doctor ratio is $119 / 100,000$ people; in DKI Jakarta it reaches $74 / 100,000$ people and in North Sulawesi it reaches 74/100,000 people.

In contrast, in several other provinces the distribution ratio of doctors are still low, among others: in West Sumatera, the doctor ratio is still 8/100,000 people, while in NTT 9/100,000 people, in NTB 12/100,000 people, Maluku and North Maluku $13 / 100,000$ people, Central and Southeast Sulawesi $14 / 100,000$ people, Lampung 15/100,000 people, and in Papua it is only $16 / 100,000$ people. Meanwhile, doctor distribution ratio compared to the number of people based on WHO standard is 40/100,000 people or 1 general practicing doctor serves 2,500-3,000 people. This condition causes WHO several years ago stated that Indonesia was included in 57 countries with a problem in equal distribution of medical 
workers. In addition to general practicing doctors, puskesmas are also facing lack of other medical workers, among others, it is recorded that 4,121 puskesmas do not have any dentist, 364 puskesmas have no midwife and 7,621 have no pharmacist

Considering the teacher and medical workers problem, it is advisable for the Government through PAN-RB Ministry to firstly focus on the distribution of employees before continuing to rationalization problem. Rationalization will only worsen lack of employees in areas that currently need more civil servants.

\section{CONCLUSION}

Civil servants rationalization policy is a good and strategic policy that aiming to improve bureaucracy performance, but such policy is hard to be implemented in short term. There are a number of hurdles and problems that must be firstly handled by the Government before the implementation of civil servants rationalization. The hurdles that must be anticipated are from regulation aspect. The Government must also firstly revise Law Number 11 of 1969 and Government Regulation Number 32 of 1979 . While the problems that must be handled is equal distribution of civil servants especially teachers and medical workers, the problems on policy and employees recruitment mechanism, employees' competence through trainings and formal education, performance and domestic expansion.

Classification determination of all state's apparatus into 4 quadrants with the approaches of performance, compability on qualification, competence and discipline are not in line with the ASN criteria desired under consideration of Law Number 5 of 2014. Several criteria that have not been considered are integrity, free from $\mathrm{KKN}$, neutral and free from political intervention, and professional civil servants. While actually those criteria are the basis in creating a clean government. If such criteria are not considered, then it will be hard to eradicate KKN practices

Improve the bureaucracy by harmonizing employees needs and improvement of bureaucracy performance must be supported by other strategic policies among others moratorium in domestic expansion. Expansion practice has inflicted the increase of domestic needs for employees. The Government should develop domestic integration policy especially for the areas that fail to reach decentralization objectives.

\section{REFERENCE}

[1] Siagian, Sondang P, 1994. Patologi Birokrasi. Galia Indonesia, Jakarta, 2000, Administrasi Pembangunan, Bumi Aksara, Jakarta.

[2] Tjokrowinoto, Muljarto, 1996. Pembangunan, Dilema dan Tantangan. Pustaka Pelajar, Yogyakarta.

[3] Kristiansen, Stein. Recovering the costs of power: Corruption in local political and civil service positions in Indonesia. Jakarta. CSIS. 2009. 